\title{
EFEK MODEL PROBLEM BASED LEARNING TERHADAP HASIL BELAJAR
}

\author{
Lenny PS Situmorang *) dan Mariati P Simanjuntak **) \\ (Prodi Pendidikan Fisika FMIPA Unimed) \\ *) Mahasiswa Pendidikan Fisika Unimed \\ ${ }^{* *}$ Dosen Fisika Unimed \\ lennysitumorang81@yahoo.co.id
}

\begin{abstract}
ABSTRAK
Penelitian ini bertujuan untuk mengetahui pengaruh penerapan model problem based learning terhadap hasil belajar fisika siswa pada materi Suhu dan Kalor di kelas X SMA Negeri 1 Laguboti T.P 2014/2015. Jenis penelitian ini adalah quasi eksperiment dengan desain control group pretest-posttest. Pengambilan sampel dilakukan dengan cara cluster random sampling dengan mengambil dua kelas dari tujuh kelas yaitu kelas X-2 sebagai kelas eksperimen yang berjumlah 34 orang dan kelas X-5 sebagai kelas kontrol yang berjumlah 32 orang. Instrumen yang digunakan berupa tes hasil belajar dalam ranah kognitif berbentuk uraian yang terdiri dari 10 soal yang sudah divalidasi dan lembar observasi untuk mengukur aktivitas, afektif dan psikomotorik. Berdasarkan hasil penelitian di kelas eksperimen diperoleh peningkatan aktivitas dalam kategori tinggi. Hasil penelitian psikomotorik termasuk dalam kategori sedang serta peningkatan afektif pada kedua kelas tergolong rendah. Persentase peningkatan hasil belajar di kelas eksperimen dalam ranah kognitif 66,4\% sedangkan di kelas kontrol 53,02\%, masing-masing dalam kategori sedang. Berdasarkan hasil uji hipotesis menggunakan uji beda (ujit) diperoleh ada efek yang signifikan penerapan model problem based learning terhadap hasil belajar fisika siswa pada materi Suhu dan Kalor di kelas X semester II SMA Negeri 1 Laguboti T.P 2014/2015.
\end{abstract}

Kata kunci : model problem based learning, hasil belajar dan aktivitas.

\begin{abstract}
This study aims to determine the effect of the applying problem based learning model on the learning outcomes of physics student on the material temperature and heat in class X Senior High School (SMA) 1 Laguboti A.Y 2014/2015. This research is quasi experiment with control group pretest-posttest design. Sampling was done by cluster random sampling by taking two classes of seventh grade is class X-2 as the experiment class numbering 34 people and class X-5 as the class control numbering 32 people. Instruments that used as a form of the test results in cognitive learning description form of illustration consisting of 10 questions that have been validated and observation sheets to measure the activity, affective and psychomotor. Based on the results of the research in the experiment class obtained the increased activity in the high category. The result of psychomotor included in the medium category and affective improvement in the both of classes is low. The percentage of the increase of the result of the study in the experiment class in
\end{abstract}


cognitive $66,4 \%$ whereas in the control class $53,02 \%$, respectively in the medium category. Based on the results of hypothesis testing by used different test (t-test) obtained that there are the significant effect application of the problem based learning model on the learning outcomes physics student on the material temperature and heat in class $X$ second semester Senior High School (SMA) 1 Laguboti A.Y 2014/2015.

Keyword : model problem based learning, learning outcomes and activit..

\section{PENDAHULUAN}

Kunandar (2007) menyatakan pendidikan di Indonesia dapat dikatakan masih rendah. Rendahnya pendidikan Indonesia dapat dilihat dari rendahnya hasil belajar siswa dalam berbagai mata pelajaran. Salah satu mata pelajaran yang memiliki nilai rendah adalah mata pelajaran fisika. Fisika merupakan cabang ilmu pengetahuan alam yang mempelajari fenomena dan gejala alam secara empiris, logis, sistematis dan rasional yang melibatkan proses dan sikap ilmiah.

Semua tenaga pendidik mengharapkan peningkatan hasil belajar yang signifikan melalui standar kelulusan yang semakin meningkat untuk tiap mata pelajaran. Namun, fakta berdasarkan observasi di SMA N 1 Laguboti dimana hasil belajar yang diperoleh siswa pada mata pelajaran IPA khususnya mata pelajaran Fisika tidak maksimal dan cenderung di bawah rata-rata. Berdasarkan hasil wawancara dengan salah seorang guru bidang studi Fisika, ternyata masalah yang terjadi di SMA Negeri 1 Laguboti diketahui nilai rata-rata hasil ujian fisika siswa semester I T. A 2013/2014 sebesar 48 dan pada T. A 2014/2015 sebesar 45 padahal nilai ketuntasan minimum yang ditetapkan adalah 68 .

Rendahnya hasil belajar siswa juga disebabkan karena suasana pembelajaran yang sifatnya berpusat pada guru (teacher centered learning) dan kurang memperhatikan keseluruhan situasi belajar dan pembelajaran yang kurang bervariasi. Pembelajaran fisika dominan menggunakan pembelajaran kovensional. Guru menjelaskan materi, menjelaskan rumus, memberi contoh soal dan memberikan PR, sehingga siswa dalam pembelajaran menjadi penerima informasi pasif dan tidak pernah dilakukan eksperimen pada saat pembelajaran sehingga siswa tidak terlibat langsung dan hanya sebagai pendengar saja.

Di sisi lain, instrumen tes hasil belajar yang biasa digunakan lebih menekankan penggunaan rumusrumus fisika, sehingga siswa hanya mampu menerapkan rumus-rumus fisika saja, sehingga keterlibatan dan keaktifan siswa masih rendah. Siswa lebih banyak belajar dengan menerima, mencatat dan menghafal pelajaran. Sebaiknya soal-soal atau instrumen yang diberikan guru harus lebih bervariasi seperti masalahmasalah dalam fisika yang berhubungan pada kehidupan seharihari, cara pemecahan masalah tersebut sehingga terdapat penerapan fisika dalam kehidupan sehari-hari, menganalisis masalah dan percobaan. Dengan adanya masalah yang diberikan kepada siswa sehingga keterlibatan siswa dan keaktifannya dalam belajarpun meningkat dan siswa dituntut untuk berpikir tingkat tinggi, berpikir 
secara kritis, melatih siswa untuk memecahkan permasalahanpermasalahan fisika dalam kehidupan sehari-hari.

Berdasarkan kenyataan tersebut, perlu diterapkan suatu model pembelajaran yang sesuai dan mampu meningkatkan aktivitas dan hasil belajar fisika siswa. Salah satu alternatif model pembelajaran yang memungkinkan diterapkan adalah model problem based learning (PBL). Arends (2008) menyatakan bahwa " problem based learning use in promoting higher-level thinking in problem-oriented situations, including learning how to learn. The essence of problem based learning consists of presenting students with authentic and meaningfull problem situation that can serve as springboards for investigations and inqury". Artinya PBL digunakan untuk bertingkat tinggi pada masalah yang berorientasi dalam berbagai situasi, termasuk mempelajari cara belajar. Inti dari pembelajaran berbasis masalah terdiri dari menyajikan siswa dengan situasi masalah yang autentik dan bermakna yang dapat berfungsi sebagai motivasi untuk investigasi dan penyelidikan.

Pembelajaran berdasarkan masalah ini dikembangkan untuk membantu siswa mengembangkan kemampuan berpikir, pemecahan masalah, dan keterampilan intelektual, belajar berbagai peran orang dewasa melalui pelibatan mereka dalam pengalaman nyata atau simulasi dan menjadi pebelajar yang otonom dan mandiri. Model problem based learning memiliki kelebihan yang salah satunya meningkatkan aktivitas pembelajaran siswa (Sanjaya, 2008). Peningkatan aktifitas siswa yaitu meningkatnya jumlah siswa yang terlibat aktif belajar, meningkatnya jumlah siswa yang berpartisipasi dalam pelaksanaan kegiatan diskusi kelompok maupun diskusi kelas, meningkatnya jumlah siswa yang menyelesaikan masalah yang autentik, dan meningktanya kecakapan dalam mempresentasikan hasil karya.

Penerapan model PBL ini sudah pernah diteliti oleh beberapa peneliti sebelumnya, seperti Sahin, (2013) menerapkan model PBL dan mendapatkan hasil bahwa ada perbedaan hasil belajar fisika yang signifikan antara kelas yang menggunakan model PBL dengan pembelajaran konvensional. Menurut hasil penelitian Selcuk (2010) diperoleh hasil skala sikap pada fisika dengan menggunakan model PBL lebih tinggi dibandingkan dengan model konvensinal. Berdasarkan hasil kedua peneliti ini diketahui bahwa ada pengaruh yang signifikan antara model pembelajaran PBL dengan model konvensional. Penelitian tersebut membuktikan bahwa model pembelajaran dapat meningkatkan hasil belajar fisika dan dapat meningkatkan skala sikap terhadap fisika.

Adapun yang menjadi tujuan penelitian ini adalah untuk menganalisis ada perbedaan yang signifikan akibat efek model problem based learning terhadap hasil belajar fisika siswa pada Suhu dan Kalor di kelas X semester II SMA Negeri 1 Laguboti T.P 2014/2015 dan menganalisis peningkatan aktivitas belajar siswa selama proses belajar mengajar dengan menggunakan model PBL.

\section{METODE PENELITIAN}

Penelitian ini dilaksanakan di SMA Negeri 1 Laguboti. Pelaksanaannya dilakukan pada siswa kelas X semester II tahun pelajaran 2014/2015. Populasi dalam 
penelitian ini adalah seluruh siswa kelas X SMA Negeri 1 Laguboti Tahun Pembelajaran 2014/2015 yang terdiri dari 7 kelas. Sampel penelitian dipilih dengan menggunakan teknik penarikan sampel kelas secara random sampling. Satu kelas dijadikan sebagai kelas eksperimen yaitu kelas X-2 yang diterapkan model problem based learning dan satu kelas lagi dijadikan sebagai kelas kontrol yaitu kelas X-5 yang diterapkan model konvensional. Jenis penelitian ini adalah penelitian quasi eksperimen. Desain penelitian yang digunakan adalah desain control group pretest-posttest. Desain penelitian ini ditunjukkan pada Tabel 1.

Tabel 1 Control Group Pretest-Posttest Design

\begin{tabular}{|l|c|c|c|}
\hline \multicolumn{1}{|c|}{ Kelas } & Pretes & Perlakuan & Postes \\
\hline Eksperimen & $O_{1}$ & $X_{1}$ & $O_{2}$ \\
\hline Kontrol & $O_{1}$ & $X_{2}$ & $O_{2}$ \\
\hline
\end{tabular}

Keterangan:

$O_{1}=$ pretes

$\mathrm{O}_{2}=$ postes

$X_{1}=$ model problem based learning

$\mathrm{X}_{2}=$ model konvensional.

Sebelum dilakukan pretes terlebih dahulu dilakukannya validitas ramalan di SMA N 5 Binjai yang bertujuan untuk mengetahui validitas, reliabilitas, tingkat kesukaran dan daya beda soal. Setelah dilakukannya pretes pada kedua kelas maka hasil pretes tersebut diuji kesamaannya dengan menggunakan uji hipotesis dua pihak menggunakan uji $t$ yaitu uji kesamaan rata-rata pretes dengan syarat data berdistribusi normal dan homogeny (Sudjana, 2005). Setelah postes dilakukan, maka hasil postes dari kelas eksperimen dan kelas kontrol diuji kesamaannya dengan menggunakan uji hipotesis satu pihak menggunakan uji $t$ yaitu uji kesamaan rata-rata postes, yang syaratnya datanya uji normal dan homogen. Peningkatan hasil belajar baik kognitif, afektif, psikomotorik dan aktivitas siswa menggunakan Ngain yang dinormalisasikan (Hake, 1998) :

$\% N-$ gain $=\frac{\text { postes }- \text { pretes }}{\text { skor maks }- \text { pretes }} \times 100$

\section{HASIL DAN PEMBAHASAN}

Setelah dilakukannya validitas tes diketahui bahwa dari 15 soal terdapat 10 soal dinyatakan valid dan 5 soal dinyatakan tidak valid. Berdasarkan perhitungan diperoleh reliabilitas tes sebesar 0,904 dengan kriteria reliabilitas sangat tinggi. Berdasarkan uji coba instrumen tes dari 15 soal, diketahui bahwa tes mempunyai taraf kesukaran berbeda yaitu 3 soal mudah, 7 soal sedang dan 5 soal sukar dan diketahui bahwa tes yang digunakan mempunyai daya beda yang berbeda-beda, yaitu 5 soal dengan daya beda cukup dan 10 soal dengan daya beda baik. Adapun hasil penelitian ini adalah bahwa nilai ratarata pretes kelas eksperimen 24,55 dan nilai rata-rata kelas kontrol sebesar 28,53.

Setelah diberikan perlakuan yang berbeda dimana pada kelas eksperimen diberikan dengan model problem based learning dan pada kelas kontrol diberikan pembelajaran konvensional, diperoleh bahwa ratarata postes kelas eksperimen sebesar 74,56 dan rata-rata kelas kontrol sebesar 66,43. Peningkatan hasil belajar kognitif untuk kelas eksperimen sebesar $66,4 \%$ termasuk dalam kategori sedang dan untuk kelas kontrol sebesar 53,02\% 
termasuk dalam kategori sedang. Peningkatan hasil belajar kognitif antara kedua kelas ditunjukkan pada Gambar 1.

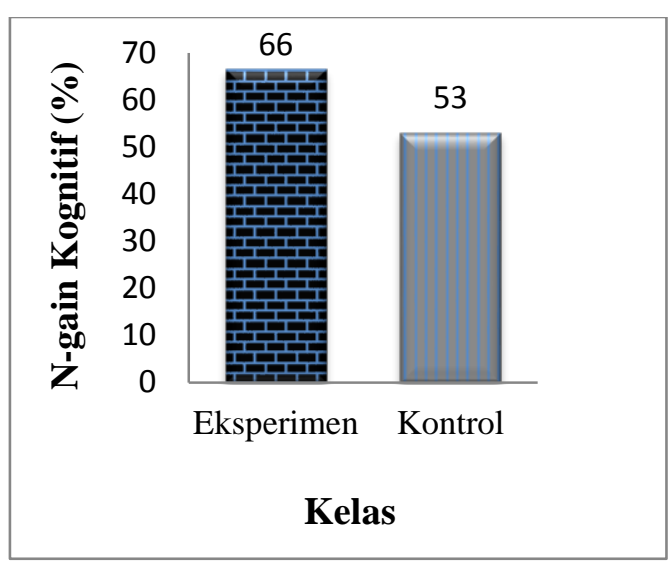

Gambar 1. Peningkatan hasil belajar kognitif antara kelas eksperimen dan kelas kontrol

Uji normalitas data pretes dan postes kelas eksperimen dan kelas kontrol menggunakan uji Lilliefors. Hasil uji normalitas data pretes dan postes kedua kelas ditunjukkan dalam Tabel 2.

Tabel 2 Uji Normalitas Data Pretes dan Postes Kedua Kelas

\begin{tabular}{|c|l|c|c|l|}
\hline Data & \multicolumn{1}{|c|}{ Kelas } & $\mathbf{L}_{\text {hitung }}$ & $\mathbf{L}_{\text {tabel }}$ & Kesimpulan \\
\hline \multirow{3}{*}{ Pretes } & Eksperimen & 0,1434 & 0,1519 & normal \\
\cline { 2 - 5 } & Kontrol & 0,0834 & 0,1566 & normal \\
\hline \multirow{2}{*}{ Postes } & Eksperimen & 0,1056 & 0,1519 & normal \\
\cline { 2 - 5 } & Kontrol & 0,1139 & 0,1566 & normal \\
\hline
\end{tabular}

Uji homogenitas menggunakan uji $\mathrm{F}$ dari data pretes dan postes kelas eksperimen dan kelas kontrol. Ternyata untuk data pretes $F_{\text {hitung }}<$ $F_{\text {tabel }}(1,24<1,84)$ dan untuk data postes $F_{\text {hitung }}<F_{\text {tabel }}(1,19<1,79)$. Ini berarti varians kedua sampel homogen pada taraf signifikan $\alpha=$ 0,10 . Uji hipotesis menggunakan uji $t$, dimaksudkan untuk melihat perbedaan hasil belajar di kelas eksperimen dan kelas kontrol akibat efek model PBL. Syarat uji $t$ ini adalah data harus berdistribusi normal dan sampel harus berasal dari populasi yang homogen. Melihat kedua syarat tersebut telah terpenuhi, maka dilakukan uji hipotesis dengan menggunakan uji t. Hasil perhitungan dengan menggunakan uji t, dengan $\alpha$ $=0,05$ pada data postes diperoleh $t_{\text {hitung }}=2,94$ sedangkan $t_{\text {tabel }}=1,669$. Dapat disimpulkan bahwa terdapat efek model problem based learning (PBL) yang signifikan terhadap hasil belajar siswa pada materi suhu dan kalor kelas X SMA N 1 Laguboti.

Aspek aktivitas yang dinilai adalah melakukan diskusi, melakukan percobaan, membuat hipotesis, memecahkan masalah, menulis hasil karya dan mempresentasikan hasil karya. Observasi aktivitas ini dilakukan di kelas yang sesuai dengan pengembangan model pembelajaran yang digunakan. Peningkatan aktivitas pada kelas eksperimen ditunjukkan pada Gambar 2.

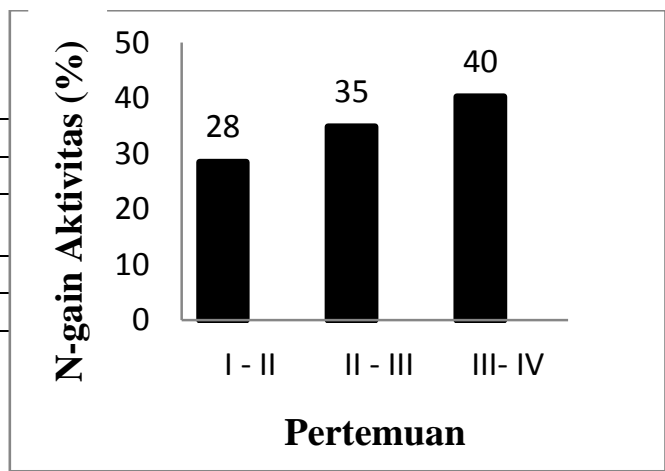

Gambqr 2. Peningkatan aktivitas tiap pertemuan

Penilaian afektif yang dinilai adalah disiplin, tanggung jawab, jujur, teliti, kreatif dan peduli. Afektif yang ditunjukkan siswa menunjukkan perubahan yang positif. Peningkatan hasil belajar afektif antara kedua kelas ditunjukkan pada Gambar 3. 


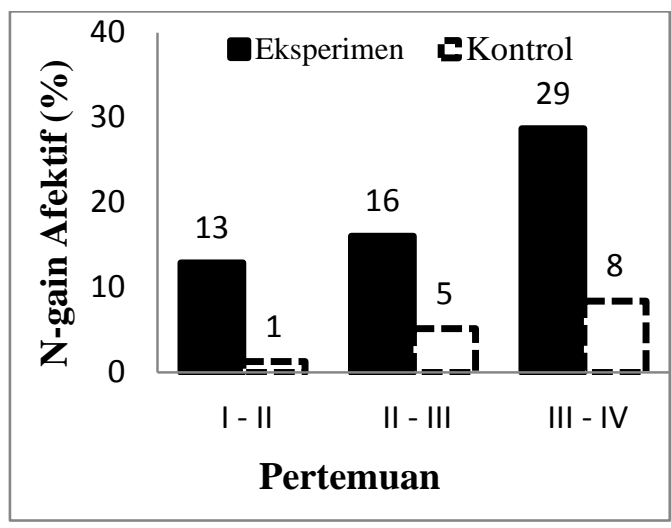

Gambar 3. Aktifitas siswa tiap pertemuan

Kriteria penilaian afektif kelas eksperimen pada pertemuan pertama hingga keempat dinyatakan baik dengan peningkatan hasil belajar afektif dinyatakan rendah, sedangkan pada pertemuan keempat dinyatakan amat baik dengan kriteria peningkatan hasil belajar afektif rendah dan kelas kontrol di setiap pertemuan dinyatakan cukup baik dengan kriteria peningkatannya rendah. Penilaian psikomotorik yang dinilai adalah merencanakan percobaan, merangkai alat, melakukan pengamatan, data yang diperoleh dan menyimpulkan percobaan. Peningkatan hasil belajar psikomotorik ditunjukkan pada Gambar 4.

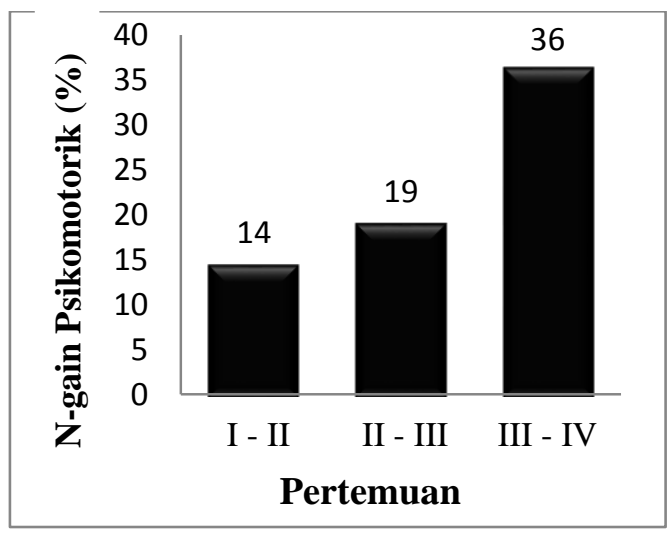

Gambar 4. Peningkatan hasil belajar psikomotorik
Hasil penelitian menunjukkan bahwa ada efek model problem based learning terhadap hasil belajar siswa pada materi Suhu dan Kalor di Kelas X Semester II SMA N 1 Laguboti. Hal ini dapat dilihat dengan adanya perbedaan hasil belajar dan hasil observasi aktivitas antara kelas eksperimen dengan kelas kontrol. Efek problem based learning memberikan perbedaan terhadap hasil belajar pada aspek kognitif dikarenakan model problem based learning mempunyai tiga konsep utama yaitu pengetahuan yang didapat dari proses penyelidikan autentik yang berupa masalah, siswa dapat mengembangkan kemampuan untuk menyimpulkan dari penyelidikan yang telah dilakukan dan siswa menganalisis unsur-unsur yang diperlukan, melaksanakan percobaan dan mempresentasikan hasil karya. Mereka harus menganalisis dan mendefinisikan masalah, mengembangkan hipotesis, dan membuat ramalan, mengumpulkan dan menganalisa informasi, melakukan eksperimen dan merumuskan kesimpulan, serta metode penyelidikan yang digunakan harus bergantung kepada masalah yang sedang dipelajari.

Selama

penelitian

berlangsung kronologi pada pertemuan pertama hingga pertemuan keempat diperoleh bahwa pada fase pertama yaitu memberikan orientasi tentang permasalahan kepada siswa, pada pertemuan pertama banyak siswa yang merasa bingung dan komentar mengenai masalah yang diberikan oleh peneliti. Mereka bingung dengan masalah yang disajikan karena mereka tidak pernah mendapatkan masalah fisika dalam pembelajaran sebelumnya 
sehingga peneliti menjelaskan berulang kembali mengenai masalah yang disajikan hingga mereka paham apa yang dimaksud pada masalah tersebut, tetapi setelah dilihat dari pertemuan kedua dan ketiga siswa semakin paham mengenai masalah yang disajikan hingga pertemuan keempat siswa tidak lagi bingung dan komentar mengenai masalah.

Fase kedua yaitu mengorganisasi siswa untuk meneliti, pertemuan pertama terjadinya keributan sesama siswa sehingga peneliti sulit untuk mengatur siswa dalam berkelompok dan siswa masih merasa bingung untuk bergabung dengan kelompoknya. Hal ini disebabkan karena siswa tidak pernah dikelompokkan dalam proses pembelajaran sehingga siswa belum terbiasa, tetapi pada pertemuan kedua hingga keempat siswa sudah semakin kondusif dalam pembentukan kelompok karena sudah semakin terbiasa.

Fase ketiga membantu investigasi mandiri dan kelompok, pada pertemuan pertama siswa tidak banyak melakukan investigasi dan mengumpulkan informasi karena hanya bermodalkan satu buku pelajaran saja. Beberapa siswa yang membawa laptop dan modem tidak digunakan untuk mencari informasi masalah fisika melainkan bermain $\mathrm{fb}$, mengedit foto, twitteran, bermain game dan lain-lain. Tetapi pada pertemuan kedua hingga keempat siswa sudah semakin terdorong untuk mencari informasi baik dari buku lain dan internet sesuai dengan arahan peneliti sebelum pertemuan berikutnya berlangsung.

Fase

mengembangkan mempresentasikan keempat dan exhibit, pada pertemuan pertama siswa masih malu-malu dan raguragu mempresentasikan hasil karya mereka. Siswa masih harus diberikan motivasi yang lebih untuk maju mempresentasikan hasil karyanya, sedangkan pada pertemuan kedua hingga ketiga siswa semakin semangat untuk mempresentasikan hasil karyanya dan sudah mulai ada siswa yang meberikan saran-saran dan pertanyaan kepada kelompok penyaji. Pada pertemuan keempat semua kelompok ingin mempresentasikan hasil karya mereka dan seamkin banyak siswa yang memberikan saran-saran dan pertanyaan sehingga siswa menjadi aktif dan pembelajaran berlangsung dengan baik.

Fase kelima menganalisis dan mengevaluasi proses mengatasi masalah, pada pertemuan pertama siswa tidak mendapatkan kendala mengevaluasi hasil karya mereka dari kelompok lainnya karena tidak adanya yang memberikan saran dan pertanyaan sehingga hanya menerima evaluasi yang diberikan oleh peneliti. Pertemuan kedua siswa sudah mulai berani mengevaluasi kelompok lain dan sudah ada beberapa siswa yang memberikan saran dan pertanyaan, dan kelompok penyaji masih merasa kesulitan dalam hal menjawab pertanyaan dari kelompok lain sehingga masih dibimbing oleh peneliti. Pertemuan ketiga dan keempat terjadinya diskusi yang aktif antara kelompok penyaji dan kelompok lainnya karena sudah siswa-siswa sudah semakin percaya diri mengungkapkan pendapat mereka baik pengevaluasian dalam bentuk saran dan pertanyaan, dan kelompok penyaji sudah semakin percaya diri 
menyampaikan jawaban-jawaban dari hasil karya mereka.

Berdasarkan uraian di atas dapat disimpulkan bahwa model PBL dapat meningkatkan keterampilan siswa dan rasa percaya diri siswa. Hal ini didukung oleh Arends (2008) pembelajaran berdasarkan masalah merupakan suatu pendekatan pembelajaran di mana siswa mengerjakan permasalahan yang autentik dengan maksud untuk menyusun pengetahuan mereka sendiri, mengembangkan inkuiri dan keterampilan berpikir tingkat lebih tinggi, mengembangkan kemandirian dan percaya diri.

Berdasarkan hasil penelitian yang dilakukan oleh Sahin (2013) ; Eldi dan Sulaiman (2013 diperoleh bahwa ada perbedaan hasil belajar siswa yang signifikan antara kelas yang menggunakan model pembelajaran berbasis masalah dan pembelajaran konvensional. Hal ini didukung oleh Tasoglu, et all., (2013) yang menyatakan menyatakan bahwa ada pengaruh hasil belajar siswa yang signifikan antara kelas yang menggunakan model problem based learning dan pembelajaran konvensional. Pembelajaran berdasarkan masalah lebih baik dari pembelajaran konvensional, dimana pemahaman konsep dan keterampilan belajar siswa yang dibelajarkan dengan pembelajaran berdasarkan masalah lebih baik dibandingkan siswa yang dibelajarkan dengan pembelajaran konvensional. Serta pembelajaran berdasarkan masalah juga meningkatkan hasil belajar secara berkelompok bukan hanya secara individu. Peningkatan hasil belajar menggunakan model problem based learning merupakan model yang cukup bagus untuk lebih memahami isi pelajaran dan membantu siswa bagaimana mentransfer pengetahuan mereka untuk memahami dan memecahkan masalah dalam kehidupan nyata.

Hal ini diperkuat dengan adanya peningkatan aktivitas di kelas eksperimen, peningkatan aktivitas belajar siswa di kelas eksperimen setiap pertemuannya meningkat. Tetapi pada saat proses belajar dilakukan tidak semuanya siswa mampu memenuhi mengikuti semua aktivitas dalam pembelajaran, terdapat beberapa siswa yang hanya duduk dikelompoknya tanpa ada melakukan apa-apa hanya diam dan pasif, tidak memberikan pendapat apapun.

Model problem based learning memiliki kelebihan yang salah satunya meningkatkan aktivitas pembelajaran siswa (Sanjaya, 2010; dan Trianto, 2009). Aktivitas siswa adalah keterlibatan siswa dalam bentuk sikap, pikiran, perhatian, dan aktivitas dalam kegiatan pembelajaran guna menunjang keberhasilan proses belajar mengajar dan memperoleh manfaat dari kegiatan tersebut. Peningkatan aktivitas siswa yaitu meningkatnya jumlah siswa yang terlibat aktif belajar, meningkatnya jumlah siswa yang berpartisipasi dalam pelaksanaan kegiatan diskusi kelompok maupun diskusi kelas, meningkatnya jumlah siswa yang menyelesaikan masalah yang autentik, dan meningktanya kecakapan dalam mempresentasikan hasil karya.

Penilaian afektif siswa pada kelas eksperimen juga meningkat setiap pertemuannya. Rata-rata persentase penilaian afektif kelas 
eksperimen dengan menggunakan model problem based learning adalah $71,51 \%$ yang termasuk dalam kategori baik. Selanjutnya, rata-rata persentase penilaian keterampilan kelas eksperimen dengan menggunakan model problem based learning adalah $70,56 \%$ yang termasuk dalam kategori baik. Pada saat proses belajar mengajar berlangsung masih ada juga siswa yang susah diatur, tidak kondusif, mengganggu teman yang lagi belajar, seperti beo dan membutuhkan waktu yang lebih banyak pada saat mengelompokkan siswa kedalam kelompok.

afektif dan perkembangan
keterampilan di kelas eksperimen didukung oleh peneliti sebelumnya Selcuk (2010), pembelajaran problem based learning memiliki hasil skala sikap fisika yang lebih tinggi daripada pembelajaran konvensional. Berdasarkan hasil penelitian diperoleh rata-rata nilai sikap sebelum diberi perlakuan dengan menggunakan model PBL sebesar 71,50 sedangkan nilai ratarata setelah diberikannya perlakuan dengan menggunakan model PBL sebesar 96,50, sehingga bisa disimpulkan bahwa model PBL dapat meningkatkan penilaian afektif siswa. Hal ini juga didukung oleh Aziz, (2014) yang mengatakan bahwa siswa yang diterapkan model PBL, mereka lebih memahami, lebih kooperatif, meningkatkan efisiensi pada pemecahan masalah, meningkatkan soft skill, dan waktu konsumen yang lebih efektif meskipun mereka merasa ada beberapa masalah teknis dan kurangnya kerjasama dari anggota kelompok serta meningkatkan keterampilan belajar mandiri. Dari penelitian tersebut dapat dilihat bahwa PBL mampu memberikan manfaat yang sangat baik untuk siswa karena dari model PBL didapatkan siswa lebih memahami materi pelajaran, lebih efisiensi dalam pemecahan masalah, meningkatkan soft skill mereka dan tentunya lebih mampu berpikir secara kritis dalam menghadapi permasalahan-permasalahan fisika dalam kehidupan sehari-hari.

Selama pembelajaran masih ada kendala yang dihadapi yaitu ketika mengorganisasikan siswa dalam kelompok, menggunakan waktu yang cukup lama dan ketidak kondusifan siswa pada saat diorganisasikan dalam kelompok oleh karena siswa di kelas ini belum terbiasa dalam pembentukan kelompok seperti yang dilaksanakan peneliti. Rasa malu dan keragu-raguan dalam pengambilan kesimpulan masih tertanam pada diri siswa, sehingga siswa mengalami kesulitan dalam mempresentasikan hasil kerja kelompoknya. Siswa juga masih bingung dengan bentuk masalah yang diberikan oleh peneliti karena siswa tidak pernah menerima soal yang berupa masalah karena siswa hanya terbiasa mengerjakan soal yang berupa aplikasi rumus matematik. Siswa terlihat bingung dengan penggunaan dan nama-nama alat yang digunakan pada saat praktikum karena tidak pernah dilakukan praktikum sebelumnya oleh guru di sekolah tersebut. Peneliti juga mengalami kendala dalam mengawasi siswa dalam setiap kelompok karena observer yang dilibatkan terbatas. Peneliti juga mengalami kendala dalam hal membuat masalah yang autentik untuk disajikan kepada siswa, peneliti berulang-ulang mengalami perbaikan masalah yang akan 
disajikan karena masalah yang dibuat oleh peneliti belum dapat dikatakan, membutuhkan waktu yang cukup lama bagi peneliti untuk mendapatkan masalah yang sebenarnya dalam permasalahan fisika. Peneliti juga mengalami kendala dalam hal mempersiapkan alat dan bahan pada saat pembelajaran hal ini diakibatkan krena sarana dan prasarana yang kurang lengkap disekolah tersebut dan wilayah yang diteliti masih belum lengkap mengenai alat-alat yang peneliti butuhkan untuk dibeli.

\section{KESIMPULAN DAN SARAN Kesimpulan}

Kesimpulan yang diperoleh berdasarkan hasil penelitian adalah hasil belajar siswa dalam aspek kognitif di kelas eksperimen dengan model problem based learning mengalami peningkatan sebesar $66,4 \%$. Hasil belajar pada penilaian afektif di kelas eksperimen pada setiap pertemuanya mengalami perkembangan dengan persentase rata-rata 71,51 dengan kategori baik dengan kategori peningkatan rendah. Hasil belajar pada penilaian psikomotor di kelas eksperimen pada setiap pertemuannya juga mengalami perkembangan dengan persentase rata-rata 70,56 dengan kategori baik dengan kategori peningkatan sedang. Hasil belajar siswa dengan menggunakan model pembelajaran konvensional khususnya pada materi suhu dan kalor memberikan nilai ratarata dengan kategori cukup baik dan peningkatan hasil belajar dengan kategori sedang. Hasil belajar siswa dalam aspek pengetahuan di kelas kontrol dengan menggunakan pembelajaran konvensional dengan nilai rata-rata 66,43 dengan peningkatan $53,02 \%$. Hasil belajar pada penilaian afektif di kelas kontrol pada setiap pertemuanya mengalami perkembangan dengan persentase rata-rata 46,04 dengan kategori cukup baik dengan kategori peningkatan rendah. Aktivitas siswa yang dikembangkan dari model problem based learning memberi informasi bahwa dapat meningkatkan keaktifan siswa dalam proses pembelajaran ditinjau dari hasil dengan kategori rata-rata aktivitas di setiap pertemuan dinyatakan aktif dan dengan peningkatannya tergolong tinggi dan ada perbedaan yang signifikan akibat efek model problem based learning (PBL) terhadap hasil belajar siswa pada materi suhu dan kalor di kelas $\mathrm{X}$ Semester II SMA Negeri 1 Laguboti T.P 2014/2015.

\section{Saran}

Saran untuk peneliti selanjutnya diharapkan agar lebih mengoptimalkan pengelolaan kelas khususnya pada saat diskusi berlangsung agar tidak terjadi kegaduhan-kegaduhan di dalam kelas, memberikan motivasi yang kuat terlebih dahulu kepada siswa yang akan mempresentasekan hasil karya untuk meningkatkan rasa percaya diri pada siswa, lebih menguasai materi karena mencari masalah dalam permasalahan fisika sangat sulit sehingga dibutuhkan pemaham dan penguasaan materi yang baik, lebih teliti dan lebih meluangkan waktu melengkapi alat dan bahan yang akan digunakan agar pembelajaran berlangsung dengan efektif dan aktif.

\section{DAFTAR PUSTAKA}

Arends, R., (2008), Learning to Teach: Belajar untuk Mengajar, Pustaka Pelajar, Yogyakarta. 
Aziz, (2014), The Effects of Problem-Based Learning on Self-Directed Learning Skills among Physics Undergraduates, Jurnal, Malaysia : Universiti Sains Malaysia, vol. 3, no. 1.

Eldy, E., and Sulaiman, F., (2013), Integrated PBL Approach: Preliminary Findings Towards Physics Students' Critical Thinking and Creative-Critical Thinking, International Journal of Humanities and Social Science Invention, vol.2, no. 3, pp.18-25.

Hake, R. (1998), InteractiveEngagement vs Traditional Methods: A Six-Thousand Student Survey of Mechanics Test Data for Introductory Physics Course, Indiana: Bloomington.

Kunandar, (2007), Guru Profesional implimentasi Tingkat Satuan Pendidikan (KTSP) dan Sukses dalam Sertifikasi Guru Edisi Revisi. Jakarta: Raja Grafindo Persada.

Sahin, (2013), A Comparison of Achievement in Problem-Based, Strategic and Traditional Learning Classes in Physics, Jurnal, Turkey : Dokuz Eylul University, vol. 4, no. 1.

Sanjaya., W., (2008), Strategi Pembelajaran Berorientasi Standar Proses Pendidikan, Prenada Media Grup, Jakarta.
Sanjaya., W, (2010), Strategi Pembelajaran Berorientasi Standar Proses Pendidikan, Prenada Media Grup, Jakarta.

Selcuk, G. S., (2010), The Effects of Problem-Based Learning on Pre-Service Teachers' Achievement, Approaches and Attitudes Towards Learning Physics, International Journal of The Physical Sciences. vol. 5(6), pp. 711-723.

Sudjana, (2005), Metode Statistik, Penerbit Tarsito, Bandung.

Tasoglu, A., and Bakac, M., (2014), The Effect of Problem Based Learning Approach on Conceptual Understanding in Teaching of Magnetism Topics, Eurasian Journal of Physics and Chemistry Education, vol 6, no.2, pp. 110-122.

Trianto, (2009), Mendesain Model Pembelajaran InovatifProgresif, Kencana, Jakarta. 